\title{
REINTERPRETING FREIRE'S ESSAY ON THE BANKING MODEL OF EDUCATION BY USING TYLER'S MODEL OF CURRICULUM
}

\author{
Sameera Sultan ${ }^{*}$
}

\begin{abstract}
The banking model manufactures human consciousness that is easy to control. It programs individuals to accept and believe in a false concept of reality so that they fail to perceive the connection between human action and their immediate and higher social reality. In this way, it creates submissive subjects for the order of oppression. The oppressed are conditioned and incapable of perceiving the truth. Their critical and creative thinking potential is systematically annulled. This paper aims to reinterpret Freire's essay on "the Banking Model of Education" using Tyler's model of curriculum to uncover the practices of the educators at every level of the oppressor-controlled educational system. As Tyler's model is often termed as a "Product model", its framework can be useful in analyzing the banking model, which is purely productoriented, to achieve deeper understanding of the process which the banking model adopts to produce a certain type of psyche that can ensure the survival of oppression.
\end{abstract}

Keywords: Banking model of education, curriculum, oppression, pedagogy, learning experiences, conscientization, problem posing education

\section{Introduction}

Freire's critique of the educational system established and implemented by the ruling elite has been a seminal work in the history of modern education. He used the term "Banking model of education" to refer to the elite-constructed educational program. Although Freire exposed the oppressor-governed system of education prevalent at his time some fifty years ago in his celebrated book Pedagogy of the Oppressed, one cannot deny the existence of the banking model in the current era. Most educational programs, especially the ones set up by the government in the third world countries, are modeled on the banking model of education. Pakistani educational system, at its heart, is pro-elite and ensures the survival and preservation of the order of oppression by creating a class of the oppressed who are submissive and incapable of critical thought. ${ }^{1}$

A peculiar quality of the banking model is the efficiency with which it creates a type of consciousness and mindset that makes one a loyal subject of the order of oppression. It employs strategies and techniques that systematically suppress the learners' critical and creative thinking potential. The banking model induces in the taught an attitude of

\footnotetext{
* Sameera Sultan, Lecturer in English, Department of Sciences and Humanities, FAST-National University of Computer and Emerging Sciences, Main Campus, Karachi

${ }^{1}$ Freire, P. (1970). Pedagogy of the Oppressed (New York. Continuum, 72)
} 
dependency on superior elite class when faced with various kinds of crisis in life. It turns learners into empty vessels capable of only but one vocation, that is, storing the deposits transferred to them by the teacher ${ }^{2}$. The oppressed remain unaware of the intellectual and creative potential that nature has bestowed upon them and start believing the falsehood that they need to be guided and directed by the elite class. In addition to curbing the intellectual potential of the oppressed, the banking model indoctrinates them to accept a false concept of reality as something that is above human existence and consequently unchangeable. This view of reality as a permanent and fixed phenomenon fosters an attitude of acceptance when faced with oppression and social injustice. The oppressed feel obliged to embrace their social reality believing it to be their destiny.

Banking model functions like a manufacturing industry. It excels in producing a passive and docile oppressed class with a false concept of reality and consciousness hard-wired into their brains.

\section{Aim and Rationale for the Study}

This paper aims to reinterpret Freire's essay on the banking model of education to explore how the banking model manages to achieve its above described objectives. To achieve this aim, this paper employs the framework of Tyler's model of curriculum to the banking model. The rationale for this is to be able to conduct an in-depth analysis of the banking model to bring to light the practices of the educators at every stage of the educational program. Tyler's model is used as it is popular as Product model ${ }^{3}$. It has been alleged to treat education as an industry that can produce individuals having predetermined specifications. These specifications are outlined in the learning objectives and achieved in a mechanical fashion by offering the right learning experiences. The banking model, on the other hand, places complete emphasis on accomplishing a clear definitive agenda. The banking model accomplishes its objectives mechanically with mathematical accuracy. The focus is on manufacturing a type of product with a well thought of psyche.

Therefore, both Tyler's model and the banking model emphasize accomplishment of already established objectives and creation of certain characteristics in the learners undergoing the educational process. For this reason, Tyler's framework is used for a microscopic inspection of the banking model which is purely product-oriented. ${ }^{4}$

\section{Tyler's Model of Curriculum}

Tyler is believed to be one of the most influential persons in the history of American education. As educator, he offered services in the fields of assessment and evaluation. He contributed heavily to the fields of education namely policy, evaluation, testing, and curriculum development.

\footnotetext{
${ }^{2}$ Ibid., (1970)

${ }^{3}$ Tyler, R. W.. Basic Principles of Curriculum and Instruction. (Chicago: The University of Chicago Press. 1949)

${ }^{4}$ Ibid.
} 
Tyler's book Basic Principles of Curriculum and Instruction has acquired the status of a Bible in the field of curriculum development. This legendary publication has shaped, impacted, and guided the views and approaches of countless curriculum planners and developers. It is critiqued, adopted, adapted, and followed all over the world in the process and field of curriculum development. ${ }^{5}$

In this book, Tyler proposes and discusses the process for designing an effective curriculum. Commonly referred to as the Tyler model, the process outlined by Tyler contains the following steps.

\section{What educational purposes should the school seek to attain?}

Tyler (1949) titles each step or stage in the process of curriculum development with a question. The first step is devoted to the selection of appropriate and relevant educational objectives for any educational program. Tyler instructs designers to use three major sources to select broad and general objectives which he terms as "goals"6. The three sources are:

a) The Students: According to Tyler (1949), useful data can be collected by analyzing students' needs and interests. The program is primarily for the students and must take into account their most vital needs, preferences, and interests.

b) The Society: The second source that can provide information regarding educational objectives that should be entertained is the society. Tyler instructs to conduct a thorough analysis of the contemporary life in the community and society at large in order to identify valid objectives. Tyler (1949) advices to categorize society life into different domains like health, family, religion, recreation, vocation, consumption, and civic roles.

c) Subject Matter: The last source to be referred to is the subject matter. Objectives must be derived from the subject matter, content, subject specialists so that the knowledge and information that is significant must be communicated.

A detailed critical analysis of the above three sources will yield numerous potential objectives which now need to be evaluated so that the most valid and relevant ones can be shortlisted and finalized. Tyler recommends applying two screens for filtering the general objectives to attain the most valid ones. The first screen to be applied is the philosophical one. The school must formulate a social and educational philosophy and select objectives that are consistent with this philosophy?

The second screen is the psychological screen. Tyler instructs the school to decide upon the principles and theory of learning that it believes to be most effective. "A psychology of learning" writes Tyler "not only includes specific and definite findings but it also involves a unified formulation of a theory of learning which helps to outline the nature of the learning process, how it takes place, under what conditions, what sort of

\footnotetext{
${ }^{5}$ Ibid.

${ }^{6}$ Ibid.

${ }^{7}$ Ibid.
} 
mechanisms operate and the like." Using this screen as criteria, valid objectives can be selected $^{8}$.

Therefore, in the end, precise, valid, and feasible objectives have been selected. The next step is as follows.

How can learning experiences be selected which are likely to be useful in attaining these objectives?

Tyler defines the term "learning experiences" as "the interaction between the learner and the external conditions in the environment to which s/he can react. Learning takes place through the active behavior of the student; it is what he does that he learns, not what the teacher does". Tyler clearly indicates that "learning experience is not the same as the content with which the course deals nor the activities performed by the teacher."

Tyler also outlines the principles and criteria for selecting useful and effective learning experiences. The next step is outlined below.

\section{How can learning experiences be organized for effective instruction?}

Tyler argues that human behavior cannot be changed overnight. Educational experiences must be so organized as to reinforce each other to produce a cumulative effect. $\mathrm{He}$ presents detailed and elaborate criteria for the organization of learning experiences.

\section{How can the effectiveness of learning experiences be evaluated?}

An important component of the curriculum is assessment and evaluation. Tyler (1949) establishes that assessment and evaluation are crucial and an important need. The teachers and educators need to find out the extent and quality of students' learning at the end of the instruction in order to determine the effectiveness of teaching methodology, the extent to which objectives have been accomplished, and the effectiveness of the organization of learning experiences. Tyler has outlined evaluation procedures to be adopted.

By referring to the Tyler model, Freire's critique of the educational system of his time can be reinterpreted and analyzed to explore the educational practices at every stage of the "Banking Model of Education".

\section{Banking Model of Education}

Freire was a Brazilian educator, philosopher, and social activist. His work has influenced people belonging to diverse fields such as education, social work, community development, literacy programs and many more.

Freire in his famous book Pedagogy of the Oppressed offers a critique of the educational system prevalent at his time in Brazil. Pedagogy of the Oppressed is a highly influential

\footnotetext{
${ }^{8}$ Ibid.
} 
book. ${ }^{9}$ It can rightfully be treated as an expose of the order of oppression and the type of educational system established and run by the oppressors to maintain the status quo. Freire uses the term "Banking Model of education" to refer to the educational and pedagogical practices of the oppressor-governed educational system. Alam writes that the term "banking model of education is by no means a positive concept". It will always create negative connotations whenever used in the academic field ${ }^{10}$. Mayo exerts that in Pedagogy of the Oppressed, Freire exposes the means that the oppressors employ to domesticate the oppressed and develop in them false consciousness. One of the major methods that these means constitute is the banking model of education ${ }^{11}$.

Freire lays bear every aspect of the educational system and practices followed by the oppressors. He critically analyzes the role of the teachers, students, pedagogical practices, assessment strategies, and the view of reality and human consciousness propagated in the banking model of education. He uses the metaphor of "banking" to describe the educational system of the oppressors. The teacher in this model is the account holder and is superior and privileged as s/he possesses knowledge or currency. The students, on the other hand, are like accounts that are empty and waiting to be filled with knowledge or currency by the privileged teachers or currency holders. Students are viewed as empty vessels who come to the class merely for receiving their deposits of knowledge. They are seen as incapable of generating currency that is knowledge themselves; therefore, inferior and need to be directed and filled. As a result, students are deemed as inferior creatures. This hierarchical relationship between the teacher and students acts as a powerful device for preparing the students to develop a dependency over knowledge bearers and later on the elite ruling class in life outside the school. The system subjugates and induces a false concept of human consciousness. Human consciousness is seen as an empty slate that can only be filled by wiser individuals. It teaches one to look for authority for guidance when faced with a challenge. The banking model denies that human beings are endowed with the gift of critical and creative thinking abilities and in this way dehumanizes individuals and indoctrinates them with whatever ideology the oppressors wish to transmit ${ }^{12}$.

Ekanem et al comments that critical attitude or intellectual independence are suppressed in the banking model of education ${ }^{13}$. In addition, Micheletti expounds that in his essay "The Banking Model of Education", Freire discusses that the prevalent educational system is characterized by "the oppressive depositing" of information by teachers into their students. Banking model is obstructive to the intellectual growth of students and turns them into "receptors of information that has no real connection with their live"14.

\footnotetext{
${ }^{9}$ Freire, P. Op.cit.

${ }^{10}$ Alam, M. M. (2013). "Banking Model of Education in Teacher-Centered Class: A Critical Assessment". Research on Humanities and Social Sciences, 3(15), 27-31.

${ }^{11}$ Mayo, P. (1995). Critical literacy and emancipatory politics: The work of Paulo Freire. International Journal of Educational Development, 15(4), 363-379.

${ }^{12}$ Freire, P. Op.cit.

${ }^{13}$ Ekanem, F. D., Ekanem, T. F. D., \& Archibong, E. I. A. (2011). Socratic Dialectics and the Banking Concept of Education: a Comparative Paradigm.

${ }^{14}$ Micheletti, G. (2010). Re-Envisioning Paulo Freire's" Banking Concept of Education". Student Pulse, 2(02)
} 
Rugut and Osman state that the objective of the banking model is to "demobilize the people within the existing establishment of power by conditioning them to accept the cultural, social, political status quo of the dominant culture" ${ }^{15}$.

Cammarota and Romero contend that although Freire had written about banking model of education some thirty years ago, the practice is still found in our schools. The rime assumption of the banking model is that "the teachers supposedly possess all the knowledge and their job is to fill students supposedly blank minds with the states official perception and understanding of the world"16.

According to Saleh, banking model ends up manipulating learners through forcing them to conform to the objectives of the dominant elite who do not wish to lose their power. By accepting their passive role in the learning process, learners encourage more manipulation to be practiced upon them ${ }^{17}$.

Stevens terms banking model as "a vertical system of teaching that involves expert teacher depositing knowledge into the heads of passive students" ${ }^{\prime 18}$.

\section{Banking Model of Education Reinterpreted Using Tyler's Model of Curriculum}

The paper aims to reinterpret Freire's essay on the banking model of education using Tyler's model of curriculum design. The application of the framework of Tyler's model of curriculum to the banking model will provide an opportunity to critically examine the practices of educators at every stage and level of the educational process. The four questions used by Tyler to represent various stages of curriculum development will be adopted for an organized and systematic scrutiny of all activities occurring in the banking model.

\section{What educational purposes should the school seek to attain?}

According to Tyler model, general learning objectives are derived from an analysis of the learners, society, and subject matter. In the banking model, the learner's needs are ignored, the society's needs are never taken into account, and the subject matter requirements are also put aside. The education does not seek to serve the society, but the oppressors. The agenda is to prepare individuals for passive and uncritical acceptance of the order of oppression as their destiny and unchangeable reality. For this reason, the banking model views human beings as "adaptable, manageable beings" 19 .

For the learners, the banking model aims to "annul their creative power" and "critical consciousness". As with society, the objective is to present a false view of reality to the

\footnotetext{
${ }^{15}$ Rugut, E. J., \& Osman, A. A. (2013). Reflection on Paulo Freire and Classroom Relevance. American International Journal of Social Sciences, V2, 2, 23-28

${ }^{16}$ Cammarota, J., \& Romero, A. (2006). A critically compassionate intellectualism for Latina/o students: Raising voices above the silencing in our schools. Multicultural education, 14(2), 16

${ }^{17}$ Saleh, S. E. (2013). "Paulo Freire's Philosophy on Contemporary Education". University Bulletin. 1(15)

${ }^{18}$ Stevens, D. (2008). "Effective Values Education".

<http://www.bioethicseducation.com/attachments/027_Effective\%20Values\%20Education.pdf>

${ }^{19}$ Freire, P. (1970), Op.cit.
} 
students. The students are encouraged to adapt to the "fragmented view of reality deposited to them". The subject matter comprises of isolated facts. The contents "which are detached from reality, disconnected from the totality that engendered them and could give them significance" form the curriculum. The de-contextualized pieces of information are nothing but merely "hollow, alienating verbosity" 20 .

The philosophy behind the curriculum preaches obedience and uncritical submission to authority in order to safeguard oppression. Obedience to authority is presented as a virtue. It is a noble cause and one's destiny to accept the order of oppression. An important feature of the philosophy operative at the heart of the banking model is the view of reality that it propagates. It views humans as isolated entities with no connection or relation with others. Individuals are seen as "abstract, unattached to the world" 21 . It discourages viewing people as related to the world; consequently, it obstructs any effort to view reality as connected to people and as something changeable. In this way, it indoctrinates people into believing that reality is above human existence and permanent and has to be accepted as destiny. Therefore, one has to adjust and adapt to their social reality. Freire states that banking model emphasizes "permanence and becomes reactionary" and brainwashes the oppressed to oppose to any change or any individual who wishes to change the social order. Thenceforth, it ensures the survival of oppression by transmitting a philosophy that dictates passivity and unquestioned submission to the oppressors $^{22}$.

The psychology of learning views human beings as "objects" denying their potential for critical and creative thought. Human consciousness is merely an empty receptacle that can be filled. Humans can be controlled, conditioned, indoctrinated, and directed as per the requirements of the rulers. They can be brainwashed to accept a false concept of reality and their intellectual abilities can be made dormant. Freire writes that "this mechanistic, static, spatialized view of consciousness transforms students into receiving objects" 23 .

Finally, the specific objectives of the education program are

- $\quad$ to discourage and suppress critical and creative thought

- to ensure that students' critical consciousness does not develop by keeping them busy in storing the deposits entrusted to them

- to blur their view of reality by presenting de-contextualized and disjointed facts so that they fail "to seek out ties which link one point to another and one problem to another" 24

${ }^{20}$ Ibid.

${ }^{21}$ Ibid.

${ }^{22}$ Ibid.

${ }^{23}$ Ibid.

${ }^{24}$ Ibid. 
To sum up, the sole beneficiary of the educational program is oppressors and the mission of the program is to create a false consciousness of a sort that can allow easy control of the psyche of the oppressed.

\section{How can learning experiences be selected which are likely to be useful in attaining these objectives?}

Tyler's term "learning experiences" has a distinct meaning. It does not refer to instructional strategies or the content selected. In fact, it refers to the experience that students are exposed to by employing different instructional methods and using appropriate content or activities. The experience that the students undergo during the class determines what they learn.

Since banking model views students as receiving objects with no prior or background knowledge, banking educators do not wish to see students active in the class. The teacher is the "depositor, prescriber, domesticator" and a superior being because of the knowledge s/he possesses. The teacher views students as empty and ignorant and thus inferior beings who need a benefactor willing to deposit the treasure of knowledge onto them. The teacher presents him/herself as the opposite of the student and in this way defines him/herself. As a result, this false perception of the learners' consciousness leads the teachers to employ ineffective teaching method constituting nothing more than narratives and "communiqués",25.

Education, thence, becomes a mere act of depositing the much needed information and knowledge. As students are viewed as having no more ability than that of a vessel that can carry and contain articles poured into it, no effort is made by the teacher to motivate students to think critically and creatively. Freire complains that banking education is "suffering from narration sickness". Ekanem et al states that "banking model provides the teacher with an easy way out encouraging in the most prominent manner the narration syndrome in the lecture-deposit-memorization-regurgitation pedagogy" 26 . Alam maintains that banking model denies the fact the learners have an intellectual potential and ends up dehumanizing people ${ }^{27}$.

Freire describes the role of the students in the banking model using terms like, "listening objects, patients, containers, receptacles". Students' innate intellectual abilities are suppressed and they are forced to belief the falsehood that knowledge creation is beyond their power, social reality is unchangeable, there can be only one possible interpretation of history, and their mere vocation is to learn, accept, and live life according to the dictates of the philosophy taught to them at school (Freire, 1965). The activities that students engage in during the class are storing, recording, preserving, and reproducing the "contents of narration" without making any attempt to comprehend what they mean. Words are recorded whether or not they make any sense to the students. The learners are never encouraged to interpret the lecture contents in the context of their real life. Freire

\footnotetext{
${ }^{25}$ Ibid.

${ }^{26}$ Ekanem, et.al. Op.cit.

${ }^{27}$ Alam, Op.cit.
} 
alleges that "the sonority of words is indeed the most devastating consequence of the banking model" 28 .

The only skill students develop from their learning experiences is that of "collecting and cataloguing" the contents of teachers' narration ${ }^{29}$. Freire states that in the banking model "the scope of action allowed to the students extends only as far as receiving, filing, and storing the deposit" ${ }^{30}$.

To sum up, the experience that the students go through in the banking model makes them passive, docile, and submissive. It fosters an attitude of indifference and resignation when faced with crisis at the societal level as the oppressed are indoctrinated to believe that reality is unchangeable and should be accepted. The oppressed remain unaware of their intellectual and creative potential. They develop the habit of relying on superior beings like their teachers to be guided and told what to think and do. They are always in search of a power figure, leader to come and liberate them from their affliction, but fail to realize that they themselves have the strength to change their reality. This anestheistized and subdued psyche is easy to control and govern. Therefore, the banking model leads individuals astray form their real mission "the vocation of reaching conscientization" ${ }^{31}$.

\section{How can learning experiences be organized for effective instruction?}

As discussed above, the learning experiences offered to the students comprise teachers' "communiqués" stored without critical reflection. The content of the lecture is alienated facts and a fragmented and false concept of reality as being dissociated from human existence and consequently permanent. The relationship and organization of content is such that an obvious connection among different items does not surface. Everything is viewed as deposits to be filed in separate cabinets where connection and overall picture is discouraged. Freire compounds that words are emptied of their concreteness and become a hollow alienating verbosity. Learning experiences are organized in such a way that the learners fail to see the connection between them and his/her real life as well as among the contents themselves. Although, at a superficial level, vertical and horizontal organization of content is ensured keeping in view the level and foundation knowledge of the learner, this organization blocks the true perception of reality by isolating facts from the real life context ${ }^{32}$.

\section{How can the effectiveness of learning experiences be evaluated?}

In the banking model, assessment strategies used to determine the extent to which educational objectives have been achieved constitute evaluating the accuracy and completeness with which the students can memorize, reproduce, and retain the deposits without critical thought. In this way, all focus is only on rote learning and memorization.

${ }^{28}$ Freire, (1970) Op.cit.

${ }^{29}$ Ibid.

${ }^{30}$ Ibid.

${ }^{31}$ Ibid.

${ }^{32}$ Ibid. 
Intellectual ability is equated with the ability to learn by heart and reproduce the communiqués issued to the students. Kahl writes, "To Freire, traditional forms of assessment are part of an oppressive educational system in which students are first filled with information and then are assessed through objective testing measures designed to demonstrate how well students have memorized the information. Such assessment do not determine how well students can analyze, interpret, and critique ideas." 33

\section{Problem Posing Education}

As opposed to the banking model, Freire proposes a new kind of education for the oppressed. He terms this new system as "Problem Posing Education". Problem posing education has as its educational agenda the awakening of students' critical consciousness. Its aim is to build their intellectual and creative capacity to the maximum possible degree so that they can take critically informed action to transform their social reality and abolish oppression.

Problem posing educators seek to "humanize individuals" through the device of education. This humanization will liberate the oppressed by equipping them with skills and power needed to fight oppression. It will spark in the oppressed the motivation for praxis which will in turn better their lives ${ }^{34}$. Dasgupta rightly point out that education has the potential to be either liberating or domesticating; it is upto the educator to decide how to utilize the power to meet what ends and Freire chooses the same device as the oppressors, but with a different intent ${ }^{35}$.

The most peculiar quality of problem posing education is its insistence on abolishing the student teacher hierarchy in the class. This is a liberating step as students no longer view the teacher as a superior being with "currency" and feel convinced that their activities in the class have more scope than mere accumulation of de-contextualized information. The teacher views him/herself as well as the students as "individuals in the process of being" "36. Therefore, the teacher learns with the students and not only builds the learners' critical thinking abilities, but also enhance his/her own understanding of the world in the light of the dialogue with the taught. The teacher, therefore, is a guide and a facilitator who initiates healthy dialogue in the class.

The second most important feature of problem posing education is that it fully acknowledges that humans are endowed with critical and creative thinking potential and bring to the class their experiences. They are not an empty slate; in fact, possess knowledge and understanding of some degree regarding different issues.

The learning experiences offered constitute the employment of the most effective teaching method, that is, dialogue. Dialogue is communication between the teacher and

\footnotetext{
${ }^{33}$ Kahl Jr, D. H. (2013). Critical communication pedagogy and assessment: Reconciling two seemingly incongruous ideas. International Journal of Communication, 7, 21

${ }_{35}^{34}$ Freire, (1970), Op.cit.

${ }^{35}$ Das Gupta, S., Fornari, A., Geer, K., Hahn, L., Kumar, V., Lee, H. J., \& Gold, M. (2006). Medical education for social justice: Paulo Freire revisited.Journal of Medical Humanities, 27(4), 245-251

${ }^{36}$ Freire, (1970), Op.cit.
} 
the taught. It is communication where the teacher invites the students to think critically and reflect about the topic under study. Every student is encouraged to participate in this dialogue by sharing his/her experience and understanding and in this way everyone contributes to the process of finding relevant solutions to different issues. Best possible learning occurs through the critical analysis of one's experiences and feelings ${ }^{37}$.

The contents of the course of study consist of topics and issues that are in every way relevant to students' life outside the class. As opposed to the banking model, the agenda of problem posing education is to create an empowering consciousness for the oppressed so that they can fulfill their true destiny of reaching conscientization. Every student is motivated to think critically. The teacher makes efforts to make students critically aware of their surroundings and social reality. Daily life problems are raised in the class, proceeded by a critical analysis in which every member of the class participates, and finally a decision is made about how to solve the issue. According to Rugut and Osman "it is not the job of the teacher to provide answers to the problems, but to help the learners achieve a form of critical thinking about the situation. Freire called this conscientozation" ${ }^{, 38}$.

Thus, contrary to the banking model, problem posing education views reality as connected to human existence. Reality is changeable and informed critical action can transform the social reality of a society. Indeed Freire rightfully terms problem posing education as "revolutionary". Micheletti states that for the problem posing educator "reality is in a constant state of change. Both the teachers and students contemplate their own reality and are then empowered to imagine otherwise. Then they act upon those considerations and thus revolutionize the current reality and advance humanity." ${ }^{39}$

In the problem posing education, students are active and work as co-investigators with the teacher to achieve deeper understanding of the topic at hand. The purpose of the problem posing education is to transmit the message that every human being is gifted with intellect which grow when one engages in critical reflection and dialogue with fellow human beings. Problem posing education places grave responsibility on every individual's shoulders to take necessary action for the betterment of his/her condition instead of relying on or waiting for a super hero to emerge to liberate the oppressed from their distress. Its mission is to free the oppressed from the intellectual slavery that the banking model imposes upon them. It produces self-actualized individuals. To sum up, Saleh states that Freire's philosophy bases itself on critical and liberating dialogue between the teacher and learners which encourages responsibility and autonomy for both $^{40}$.

\section{Conclusion}

The banking model manufactures docile and submissive subjects for the oppressors. It serves the interests of the ruling elite and treats the oppressed as "objects" that need to

\footnotetext{
${ }^{37}$ Rugut, et.al. Op.cit.

${ }^{38}$ Ibid.

${ }^{39}$ Micheletti, G. (2010). Re-Envisioning Paulo Freire's" Banking Concept of Education". Student Pulse, 2(02)

${ }^{40}$ Saleh, Op.cit.
} 
be filled with a false concept of reality so that they can be easily controlled and governed. It creates a consciousness that renders the oppressed handicapped when it comes to practicing the vocation of reaching "conscientization". The oppressed remain unaware of their true destiny and are dehumanized.

The efficiency with which the banking model produces conditioned subjects calls for more research into the practices of the educators in this model. Tyler's model is regarded as an industrial construct that can quite mechanically create students with specifications enlisted in the learning objectives. Therefore, Tyler's model was applied to Freire's essay on the banking model to reinterpret the oppressive educational system. The aim was to obtain a deeper insight into the practices of educators at every stage of the educational program. Tyler titled each stage in the process of curriculum development with a question. The four questions were adopted and used to uncover the activities of the banking model educators (Freire's essay) at every level of the educational program.

As a result of the analysis, it was found that the agenda of the banking model is to create a type of consciousness that is characterized by passivity, indifference, and ignorance in regards with human intellectual potential. The aim is to indoctrinate the oppressed to embrace a false and deceptive view of reality that clashes with the beat interests of the oppressed class. Oppression is accepted as one's destiny.

The learning experiences comprise of exposing students to the narrations and communiqués issued by the authoritative teacher. The teacher behaves as a superior being due to the knowledge he/she possesses. It is only the teacher's right to use cognitive abilities. On the other hand, the learners' prime and sole duty is to store, record, memorize, and reproduce the deposits whether or not they understand them.

The content of the narration is removed from the context that could give it meaning. Disjointed, fragmented, isolated, and irrelevant information is transmitted to the students to blur the true picture of the world. The content is never connected to students' real life experiences.

The assessment strategies used are designing tests and other means that can test the degree to which learners can recall, reproduce, and remember the contents of teachers' narration. Students' understanding and critical thinking abilities are not tested.

As opposed to the banking model, Freire proposes the revolutionary problem posing education. Problem posing education seeks to liberate the oppressed from the mental slavery and deception imposed unto them. Its agenda is to put the individuals onto the path that would allow them to fulfill their destiny of reaching conscientization and humanization. The critical and creative thinking faculties of the oppressed are developed and they are made to realize that reality is a dynamic entity that can be changed. The oppressed are motivated to take critical action to change their world and continue action reflection and action to make the world a better place for everyone. 


\section{Bibliography}

Alam, M. M. (2013). "Banking Model of Education in Teacher-Centered Class: A Critical Assessment”. Research on Humanities and Social Sciences, 3(15).

Cammarota, J., \& Romero, A. (2006). A critically compassionate intellectualism for Latina/o students: Raising voices above the silencing in our schools. Multicultural education, 14(2).

Das Gupta, S., Fornari, A., Geer, K., Hahn, L., Kumar, V., Lee, H. J., \& Gold, M. (2006). Medical education for social justice: Paulo Freire revisited.Journal of Medical Humanities, 27(4).

Ekanem, F. D., Ekanem, T. F. D., \& Archibong, E. I. A. (2011). Socratic Dialectics and the Banking Concept of Education: a Comparative Paradigm.

Freire, P. (1970). Pedagogy of the Oppressed (New York. Continuum, 72).

Kahl Jr, D. H. (2013). Critical communication pedagogy and assessment: Reconciling two seemingly incongruous ideas. International Journal of Communication, 7, 21.

Mayo, P. (1995). Critical literacy and emancipatory politics: The work of Paulo Freire. International Journal of Educational Development, 15(4).

Micheletti, G. (2010). Re-Envisioning Paulo Freire's" Banking Concept of Education". Student Pulse, 2(02).

Rugut, E. J., \& Osman, A. A. (2013). Reflection on Paulo Freire and Classroom Relevance. American International Journal of Social Sciences, V2, 2.

Saleh, S. E. (2013). "Paulo Freire's Philosophy on Contemporary Education". University Bulletin. 1(15).

Sharma, M. (2006). Applying Freirian model for development and evaluation of community-based rehabilitation programmes. Asian Pacific Disability Rehabilitation Journal, 17(1).

Stevens, D. (2008). "Effective Values Education".

<http://www.bioethicseducation.com/attachments/027_Effective\%20Values\%20Educati on.pdf $>$

Tyler, R. W. (1949). Basic Principles of Curriculum and Instruction. Chicago: The University of Chicago Press. 